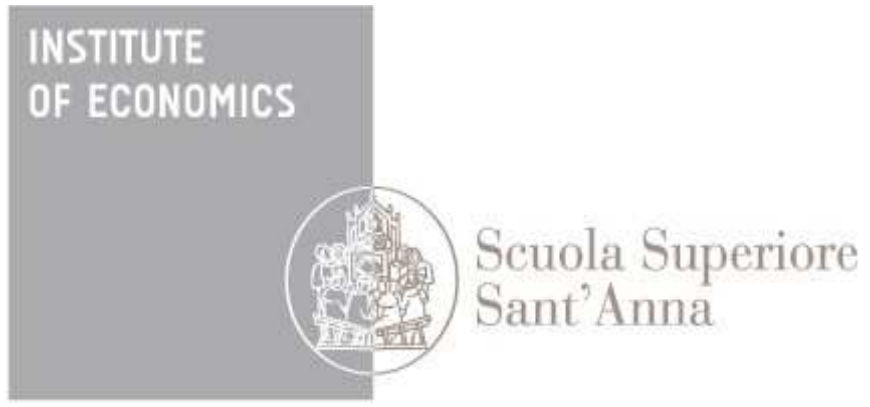

LEM | Laboratory of Economics and Management

Institute of Economics

Scuola Superiore Sant'Anna

Piazza Martiri della Libertà, 33 - 56127 Pisa, Italy ph. +3905088.33 .43$

institute.economics@sssup.it

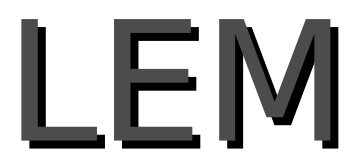

Working Paper Series

\title{
Exploring the link between Innovation and Growth in Chilean firms
}

Caterina Santi ${ }^{\circ}$

Pietro Santoleri ${ }^{\circ}$

${ }^{\circ}$ Institute of Economics, Scuola Superiore Sant'Anna, Pisa, Italy

\section{6/09 March 2016}

ISSN(ONLINE) 2284-0400 


\title{
Exploring the link between Innovation and Growth in Chilean firms
}

\author{
Caterina Santi* Pietro Santoleri ${ }^{\dagger}$
}

\begin{abstract}
We employ a balanced panel dataset representative of the entire Chilean productive structure in order to investigate the relation between the introduction of innovation and subsequent firm growth in terms of sales. Recent contributions examining the returns to innovation on firm performance have stressed the need of going beyond the analysis of the 'average effect for the average firm'. However, previous studies in the case of Latin American economies have often overlooked the importance of analyzing which firms benefit more from the introduction of innovations. Our analysis consists of a series of parametric and non-parametric exercises which take into account the properties of the firm growth distribution. In particular, we adopt quantile treatment effects (QTE) which allow to estimate the effect of the introduction of innovation by comparing firms with a similar propensity to innovate for different quantiles of the firm growth distribution. On one hand, our results indicate that process innovation shows a positive and significant relation with firm growth for those firms located at the 75th and 90th percentiles. On the other, product innovation shows a negative association only for high-growth firms.
\end{abstract}

Keywords: innovation, firm growth, Chile, quantile regression, quantile treatment effects

JEL classification: C14, C21, C22, D22, O31.

\section{Introduction}

Latin America lags behind the OECD economies in terms of innovation and technology adoption. Contrarily to East-Asian countries which have narrowed their technological gaps by making their productive structures more complex and knowledge-intensive, Latin American economies have made little progress in this area throughout the last decades. Within this region, a particular case is represented by Chile. Indeed, despite having the highest GDP per capita in Latin America, this country still features low expenditures on R\&D (0.35\% of GDP, the 7th economy in Latin America) (OECD/World Bank, 2015). One of the reasons for such limited efforts in developing domestic capabilities to generate and

*Institute of Economics, Scuola Superiore Sant'Anna - c.santi@sssup.it

$\dagger$ Institute of Economics, Scuola Superiore Sant'Anna - p.santoleri@sssup.it

${ }^{1}$ Acknowledgments The authors would like to thank Federico Tamagni, Angelo Secchi, Stefano Bianchini, Le Li, Nanditha Mathew, Ernest Migueléz for their helpful comments and suggestions. Thanks are also due to the participants to the DRUID Academy conference at Bordeaux University and to the 3rd Ph.D. workshop in Economics of Innovation, Complexity and Knowledge at Collegio Carlo Alberto in Turin. 
manage technological change has been the tendency of the business sector not to prioritise innovation and technological development (OECD/ECLAC, 2013). In fact, the private sector contributes only for the $32 \%$ to the total R\&D domestic expenditures, one of the lowest figures worldwide (the average for OECD countries is 68\%) (OECD/World Bank, 2015). These limited efforts in improving domestic technological capabilities are, in turn, observable in the degree of novelty of the innovations commercialized by Chilean firms. For instance, compared with other Latin American countries, Chile has one of the lowest shares in terms of new-to-the-world product innovations while the bulk refers to new-to-the-firm products (Casanova et al., 2011).

Given this context, the aim of this study is to shed more light on the link between the introduction of technological innovations and firm growth in the Chilean business sector. While previous contributions have focused on the nexus between innovation and productivity (Benavente, 2006; Alvarez et al., 2010, 2012) or employment growth (Benavente and Lauterbach, 2008; Alvarez et al., 2011), the link between innovation and growth in terms of sales at the firm level has not been explicitly investigated in the case of Chile.

Empirical evidence on the expected beneficial effects of innovation is still not conclusive and calls for further exploration especially in the case of less developed countries. Recent contributions show that the traditional empirical approach focusing on the 'average effect for the average firm' has mostly yielded inconclusive result, while the use of quantile regressions (QR) has unveiled that innovation is important for a minority of fast-growing firms located at the upper quantiles of the growth rate distribution (Moreno and Coad, 2015). Contrarily to recent studies regarding high-income economies, previous research in the case of Latin American countries did not go beyond the analysis of the returns to innovation for the average firm. This represents a significant shortcoming of the existing literature given the historical presence of structural heterogeneity (Pinto, 1970; Sunkel, 1978) which is reflected in huge differentials in terms of firms' productivity, resources, technological capabilities, access to foreign markets etc. among different firm sizes and between and within sectors (Cimoli et al., 2005; Santoleri and Stumpo, 2011; OECD/ECLAC, 2013; Catela et al., 2015).

Therefore, we employ QR techniques to disentangle how the returns to innovation are associated with firms located at different quantiles of the firm growth distribution.

However, traditional QR yield estimates through the comparison among potentially very different firms in terms of their propensity to introduce innovation. Thus, we provide additional evidence exploiting recent econometric developments in quantile treatment effects (QTE) (Firpo, 2007) which allow to estimate the effect of innovation on subsequent sales growth by comparing similar firms in terms of their propensity to introduce innovations.

We also assess this relation following Hall and Mairesse (2006) who suggest to examine a longer time span and not just the simultaneous effect of innovation on firm growth.

In order to do that, we exploit a recently published balanced panel data set - Encuesta Longitudinal de Empresas - longitudinally tracking Chilean firms throughout the years 2007, 2009 and 2013. Unlike most studies employing Innovation Surveys - where growth and innovations refer to the same time period due to the cross-sectional structure - our dataset allows to examine the association of innovations with subsequent sales growth at the firm level. Also, we must stress that this dataset does not suffer from typical Innovation Surveybias: that is, the data collection process does not discriminate between innovating or noninnovating firms and therefore we do not have to correct for potential selectivity biases (Mairesse and Mohnen, 2010). Finally, our sample is representative of the whole productive structure while most of the contributions in this field have examined only manufacturing or relatively large high/medium-tech firms featured in Innovation Surveys. 
The results indicate that there is a considerable difference when employing QTE compared with traditional QR. We find that process innovation is significantly and positively associated with subsequent sales growth at the 75th and 90th percentiles of the firm growth distribution. However, we find product innovation to be negatively associated with sales growth for those firms at the 90th percentile.

The remainder of the paper is as follows. In the next section we review significant contributions in the field. In Section 3 we describe the data employed along with some descriptive statistics regarding the main variables. In Section 4 we describe the econometric procedure to investigate the relation between innovation and firm growth, while in Section 5 and 6 we discuss our empirical results. Finally, Section 7 presents the conclusions.

\section{Related Literature}

A number of models stemming from different theoretical traditions have considered the importance of innovation for firm growth (Nelson and Winter, 1982; Jovanovic, 1982; Ericson and Pakes, 1995; Aghion and Howitt, 2005). However, empirical works examining this relation have had difficulties in confirming the theoretical intuitions (Coad and Rao, 2008). Studies such as Geroski et al. (1997), Geroski (2002) and Bottazzi et al. (2001) failed to find a significant effect of innovation on growth while others even yielded a negative one (Freel and Robson, 2004). The reason for this can be related to the very nature of the growth rate distributions which are characterized by fat-tails (Bottazzi and Secchi, 2006) and by the fact that the average firm doesn't grow very much entailing the need of examining fast-growing firms. Indeed, recent contributions employing QR (Koenker and Bassett Jr, 1978) reveal that innovation activities (measured as R\&D or patents) do play a significant role for those firms located at the top of the firm growth distribution (Coad and Rao, 2008; Coad, 2009; Goedhuys and Sleuwaegen, 2010; Hölzl, 2009; Falk, 2012; Colombelli et al., 2013; Bartelsman et al., 2014; Mazzucato and Parris, 2015).

However, the studies which go beyond the analysis at the mean firm growth have dealt so far with countries at the technological frontier with only few exceptions. Among them, Goedhuys and Sleuwaegen (2010) study manufacturing firms in 11 Sub-Saharan African countries and show that product innovation positively affects employment growth for businesses located at the highest percentiles of the firm growth distribution. Damijan et al. (2012), who focuses on Slovenia, find that firms at the bottom of the productivity growth distribution benefit more from product and process innovation than firms at the top of the distribution.

Recent contributions have also exploited matching techniques to investigate the effects of different measures of innovation output on firm performance. These methods allow to estimate the innovation effects by comparing characteristics of similar firms in such a way that the only difference among them is the successful introduction of innovation. Cozza et al. (2012), using a sample of medium and high-tech Italian manufacturing firms, find a positive and significant 'innovation premium' in terms of profitability and growth for those firms which introduced innovative products. Kannebley Jr et al. (2010) investigate the effects of technological innovation on several measures of firm performance for a sample of manufacturing firms in Brazil. Their findings indicate that product innovation alone does not have a significant impact on performance while process innovation does exert a positive effect. However, product innovation appears to have a significant effect when considering the degrees of novelty (innovation new-to-the-firm or new-to-the-market) or when jointly 
undertaken with process innovation. Alvarez et al. (2010) use matching techniques to investigate the effects of introducing a new product for different measures of firm performance in the Chilean manufacturing industry. Results show that the introduction of a new product does not have an effect on productivity or employment growth, while it has a positive one on current and subsequent sales growth. Moreover, Hölzl and Friesenbichler (2010) explored the differences in the innovation behaviour of high-growth firms for $16 \mathrm{EU}$ countries. The results highlighted that high-growth firms in countries at the technological frontier are more innovative and tend to have a higher $R \& D$ intensity than average-growth firms, while $R \& D$ and innovation lose relevance as distinguishing features of high-growth and average-growth firms in countries that are more distant to the technological frontier.

With respect to Latin American firms, studies have mainly drawn upon the so-called Crépon-Duguet-Mairesse (CDM) model (Crépon et al., 1998) to estimate the contribution of innovation activities on the average firm's productivity growth. The findings are mixed for Latin American economies: Raffo et al. (2008) find a significant impact of product innovation for Brazil and Mexico but not for Argentina; Pérez et al. (2005), Chudnovsky et al. (2006) do not find significant effect of innovation on firms productivity in Argentinean firms. On the other hand, Goedhuys and Veugelers (2012) find that innovation is an important driver for sales growth in Brazilian firms: in particular, the combination between product and process innovations significantly improves firm growth.

In the case of Chile, previous contributions have focused on the links between i) innovationproductivity growth (Benavente, 2006; Alvarez et al., 2010, 2012) and ii) innovation-employment growth (Benavente and Lauterbach, 2008; Alvarez et al., 2010). Regarding the innovationproductivity growth relation for manufacturing firms, Benavente (2006) finds no positive and significant effect of innovation on productivity growth while Alvarez et al. (2010) show that product innovation has a significant effect on productivity two years after its introduction but no simultaneous effect. Alvarez et al. (2012) found that for both sectors technological innovation appears as an important determinants of labor productivity. Concerning innovation and employment growth, the evidence suggests that process innovation is generally found not to be a determinant of employment growth in Chilean manufacturing plants while product innovation is positively associated with an expansion of employment (Benavente and Lauterbach, 2008; Alvarez et al., 2010). In sum, recent empirical evidence found more homogeneous results concerning the impact of innovation on employment growth, while the evidence related to the innovation-productivity growth nexus are less clear-cut for Chilean firms.

Previous literature has put forward some conjectures regarding the mixed results. Hall and Mairesse (2006) suggest that these results may be the consequence of the very differing circumstances under which innovation activities are carried out in these countries as compared to developed economies and they suggest to examine the effects over longer periods of time. Bogliacino et al. (2009) and Crespi and Zuniga (2012) maintain that the innovation process in less developed countries differ from high-income economies: in the former, stronger R\&D capabilities and science and technology infrastructure are essential to develop the required knowledge and competences to operate at the technological frontier; in the latter, technological change mainly consists of acquiring new machinery and imitate products and processes developed elsewhere (Vivarelli, 2014). In other words, innovation activities carried out in many Latin American countries are incremental with little incidence on international markets and are mainly based on imitation and technology transfer.

The presence of these specificities concerning the innovation process in less developed countries may lead to the mismeasurement of innovation output associated with indicators 
of standard use. According to Cassoni and Ramada-Sarasola (2012) "since new products do not constitute the core of innovation in non-developed economies, standard innovation output indicators - the share of innovative sales; the accumulated number of patents - would not act as good proxy variables whenever most firms are process-innovative" (p.143).

With respect to Chile, Alvarez et al. (2010) claims that the empirical evidence "might be consistent with a very slow process of learning by doing in the mastering of new production processes on the part of Chilean firms. These slow and, most of the time uncertain, gains in productivity could help to explain the low levels of investment in R\&D activities by Chilean firms".

\section{Data}

In order to conduct the study, we exploit three waves of a rich dataset released by the Ministerio de Economia (2009, 2012, 2015): the Encuesta Longitudinal de Empresas ${ }^{1}$ (ELE). In each wave a part of the sample is fixed while the other part is renewed every time. This permits analyzing variations over time for those firms observed in different waves. In order to implement the empirical strategy outlined in Section 4, we merged observations regarding firms appearing in each wave. By doing this, we obtain a balanced panel of 1,839 formal businesses stratified by economic sectors ( 1 digit ISIC rev. 3 codes) and firm size (considering the level of sales) covering the years 2007, 2009 and $2013(t=1,2,3)^{2}$. We have to highlight two features of this survey which are important for the outcome of our analysis: it represents formal businesses and includes micro enterprises starting from 800 UF worth annual sales ${ }^{3}$. As previously mentioned, the sample allows us to get a complete picture of the entire productive structure than other available surveys (see for instance ENIA for manufacturing firms and the Chilean Innovation Survey focused mainly on high/medium tech firms). Also, we must stress that this dataset does not suffer from typical Innovation Survey-bias: that is, the data collection process does not discriminate between innovating or non-innovating firms and therefore we do not have to correct for potential selectivity biases (Mairesse and Mohnen, 2010).

We cleaned the data in the following way: first, we selected only firms with at least one employee; second, we eliminated firms with missing sales; third, we restricted observations to those firms with an average annual sales growth lower than $500 \%$ in order to control for the presence of growth processes derived from mergers and acquisitions and anomalies in the data ${ }^{4}$. In the end, we are then left with a sample of 1,668 firms observed for two time periods (see Table 3 for the structure of the dataset). Table 8 in the Appendix shows the distribution of the unweighted sample across industries and firm sizes which is mainly composed by small (27 per cent) and large businesses ( 45 per cent) in the Retail (20 per cent) and Manufacturing (15 per cent) sectors.

\footnotetext{
${ }^{1}$ This survey has been little exploited so far with some exceptions being Álvarez and Crespi (2015), Cirillo (2014) and Santoleri (2015).

${ }^{2}$ Since the third wave of the ELE provides firm revenues for 2012 in the 3rd wave, we employ 2012 instead of 2013 in the analysis in order to have more homogeneous time intervals.

${ }^{3}$ It corresponds approximately to 31,000 USD (1 UF $=$ to 39 USD). Firm sizes are stratified according to the following segmentation: micro (800-2,400 UF), small (2,400-25,000 UF), medium (25,000-100,000 UF) and large $(100,000$ or more).

${ }^{4}$ This cleaning procedure concerning the growth rates led to the exclusion of 57 firms. Since the setting of the $500 \%$ threshold could be considered somewhat discretionary, we conducted the analysis also using a lower and a higher threshold of, respectively, $400 \%$ and $600 \%$ and results do not change.
} 
Table 1: The structure of the balanced panel

\begin{tabular}{cccc}
\hline Year & Time & Growth $_{t}$ & Inno $_{t-1}$ \\
\hline 2007 & $\mathrm{~T}_{1}$ & - & Inno $_{1}$ \\
2009 & $\mathrm{~T}_{2}$ & $\mathrm{G}_{1}$ & Inno $_{2}$ \\
2012 & $\mathrm{~T}_{3}$ & $\mathrm{G}_{2}$ & - \\
\hline
\end{tabular}

\subsection{Firm Growth}

Following previous literature, we define the annual average firms' growth rate as:

$$
G r_{i, t}=\frac{\ln \left(S_{i, t}\right)-\ln \left(S_{i, t-d}\right)}{d},
$$

where $S_{i, t}$ is the firm sales at time $t$ and $S_{i, t-d}$ is its value $d$ years before ${ }^{5}$. Sales are deflated using the Chilean GDP deflator (base year 2008) drawn by the Central Bank database.

Figure 1 shows the distribution of firm growth rates. In line with other empirical contributions (Bottazzi and Secchi, 2006; Coad, 2009), we can observe that sales growth are not normally distributed. Indeed, they exhibit excess values close to the mean and fat-tails which prevent using Gaussian assumptions. Hence, the properties of the data motivate us to adopt QR and QTE approach in the empirical analysis.

Figure 1: Empirical firm growth distribution

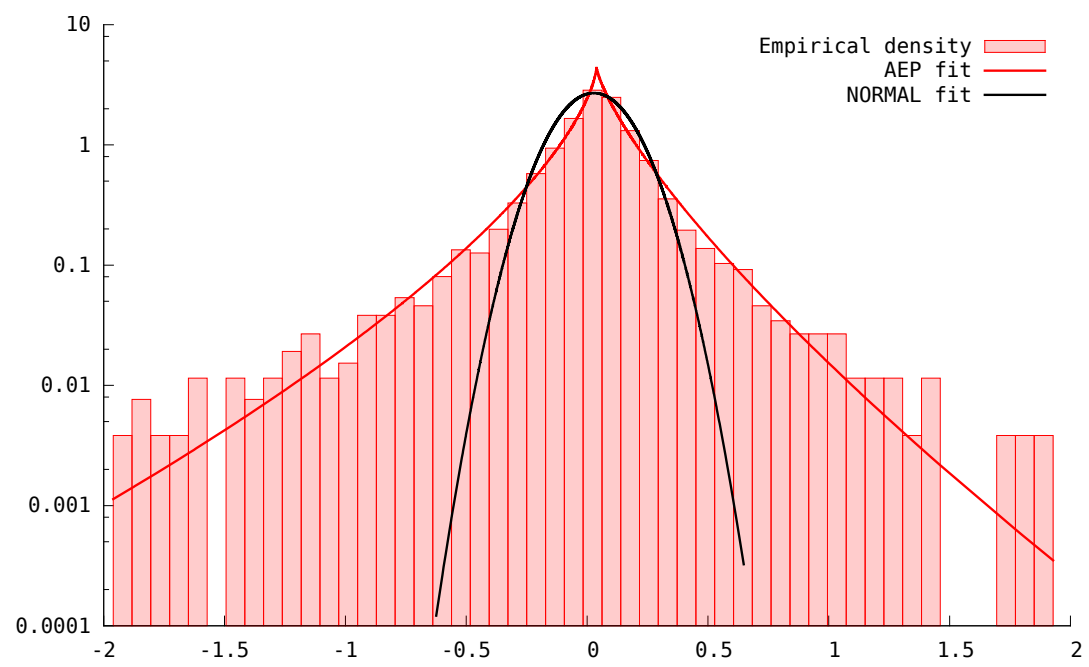

Source: Authors' elaboration based on ELE. Growth computed with eq.1. Note the y-axis is on log-scale. The parameter $b_{r}$ is 0.75 and $b_{l}$ is 0.66 confirming the non-normal distribution (see Bottazzi and Secchi (2011) for more details on the AEP distribution).

\footnotetext{
${ }^{5}$ As Audretsch et al. (2014) pointed out, the indicators used to measure growth are not neutral with respect to empirical results. Different measures describe different patterns of growth (Delmar et al., 2003). For this reason, we introduce an alternative growth rate measure to conduct a robustness check, the results are shown in Section 8.1
} 


\subsection{Innovation variables}

The ELE provides data on a wide range of issues. With respect to technological innovation, drawing on the OSLO Manual (OECD, 2005), the ELE defines product and process innovation as follows:

- A product innovation (InnoProd) is the introduction of a good or service that is new or significantly improved with respect to its characteristics or intended uses. This includes significant improvements in technical specifications, components and materials, incorporated software, user friendliness or other functional characteristics.

- A process innovation (InnoProc) is the implementation of a new or significantly improved production or delivery method. This includes significant changes in techniques, equipment and/or software.

In order to investigate the relation between these activities and subsequent firm growth, we employ dichotomous variables indicating whether or not a firm implemented an innovation during one of the years covered by the survey ${ }^{6}$.

As shown in Table 8 in the Appendix, firms successfully innovating in product and process are, respectively, 27 and 24 per cent. Those figures are in line with the results of the Chilean Innovation Survey: the innovation rate, that is, the percentage of firms which carried out some kind of innovation, is 23.7\% for the years 2011-2012 (Ministerio de Economia, 2014).

Unfortunately, the dataset does not feature any additional information regarding the quality of the innovation, e.g. if it is new-to-the-firm or new-to-the-market, or the outcome of the introduction of an innovation on business performance, e.g. share of innovative products in firm's turnover. Although the ELE does not provide more detailed data regarding the quality of the innovation outcome in Chilean firms, we should bear in mind that in less developed countries, the very nature of innovation differs from countries at the technological frontier. While in the latter the introduction of a new product often means placing it on the world market, in less developed countries the degree of novelty generally extends only to domestic markets since firms display a very limited capacity in terms of in-house R\&D (Hall and Mairesse, 2006; Bogliacino et al., 2009). Indeed, if we compare data from the Chilean Innovation Survey (Ministerio de Economia, 2014) to the ones of the European Community Innovation Survey (Eurostat, 2013) we can observe a significant difference in the degree of innovation novelty: in Chile only 34 per cent of the product innovations are new to the market, whereas in countries such as France, Italy, Norway and the Netherlands those reach, respectively, 66, 61, 79 and 67 per cent. Moreover, as previously mentioned, the degree of novelty of the innovations commercialized by Chilean firms appear to be relatively low even when compared with other Latin American economies (Casanova et al., 2011). These considerations are important since it is likely that our explanatory variable is capturing product innovation characterized by a relatively low degree of novelty.

\subsection{Control Variables}

Several other factors are likely to influence the propensity of a firm to grow. Thus, in order to examine how and whether innovation influences growth, one needs to control for

\footnotetext{
${ }^{6}$ We must stress that, while the 2 nd and 3rd waves feature detailed information concerning R\&D activities, the 1st one collects data on R\&D which are not strictly comparable with those present in other waves and, therefore, we restrain from investigating the association between conducting R\&D and subsequent firm growth.
} 
alternative determinants of firm performance. According to Gibrat's law (Gibrat, 1931), firm growth rates are independent of firm size. However, empirical evidence shows that smaller and younger firms have higher expected growth rates than older and larger firms (Mansfield, 1962; Coad, 2009). Therefore firm size is included as an explanatory variable expressed as the logarithm of the number of employees (Employment). We control for firm age $(A g e)$ since previous contribution have highlighted its relevance for firm performance (Coad, 2009; Coad et al., 2013; Haltiwanger et al., 2013). According to Pavitt (1984), the propensity to innovate varies among industries because technological opportunities are uneven across economic activities. Following this approach, 12 sectoral dummies (ISIC rev. 3) are employed in our regression analysis to control for potential sectoral systematic differences. Moreover, the export status of a firm could act as a driver of higher growth and therefore we include a variable identifying the intensity of exports by Chilean firms measured as the percentage of exports over total sales (Expint). The degree of foreign ownership is another factor potentially affecting growth as it offers businesses wider access to skilled staff and potentially enables businesses to respond more quickly to opportunities overseas. However, empirical results have shown that the relation is ambiguous and depends on the type of FDI and the country of origin of the firm (Chudnovsky et al., 2006). We capture foreign ownership with a dummy variable measuring whether part of the firm's capital is foreign owned (Foreign). Previous studies have emphasized the importance of market concentration within sectors as an important determinant of firm growth (Geroski, 1995). Indeed, there might be considerable barriers to entry and growth in industries with high market concentration, where large incumbents might engage in strategic behaviour to prevent growth of smaller firms (Geroski, 1995; Nickell, 1996; Lever and Nieuwenhuijsen, 1999). For this reason, we construct the Herfindahl Index (Herfin) in order to control for concentration at the sectoral level calculated by the sum of the squared firm market share within each industry. We also include the percentage of employees with tertiary education $(H C)$ as a proxy of human capital since this is expected to positively stimulate growth (Goedhuys and Sleuwaegen, 2016). Finally, we insert a dummy variable measuring whether the firm is part of a business group (Group) and a dummy indicating whether a firm has received public support through productive development policies implemented by the Chilean Government (Public).

Table 2 presents the average sales growth conditional upon past innovation activities and the average of the control variables conditional upon contemporaneous innovation activities for the pooled sample. On average, firms that innovate have higher levels of sales in the same period and higher rates of sales growth in the following period. The only exception is represented by those firms conducting product innovation: although they have a higher level of sales, firms that introduced this type of innovation at $t-1$ experience lower growth rates at time $t$ on average. Moreover, innovating firms display a considerably larger size (in terms of employment) along with a larger share of employees with tertiary education, higher export intensity (measured as exports over total sales) and they are generally older than non-innovating firms. Additionally, innovators are more often part of a business group and owned by foreign capital, they more frequently benefit from public subsidies and, as observed by Geroski and Machin (1992), generally operate in sectors with slightly higher concentration. 
Table 2: Mean values for innovating and non-innovating firms

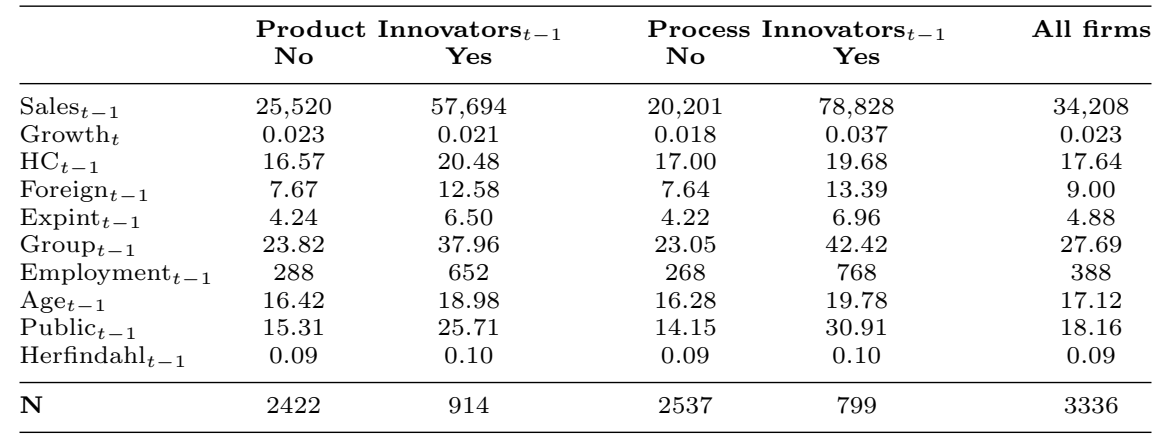

Source: Authors' elaboration based on ELE. Note that Sales is in millions of Chilean Pesos while Growth is expressed in logarithmic terms. Expint, Foreign, Group and Public are expressed in percentages.

\section{Methodology}

We start investigating the relationship between sales growth and innovation by comparing the growth rate distribution among innovators and non-innovators along each innovation variable. We perform a two-sample Fligner-Policello (FP) robust rank order test (Fligner and Policello, 1981) to check if the sales growth rates of innovators and non-innovators are sampled from the same population. This test assumes that the groups of innovators and non-innovators are independent samples from continuous distributions symmetric with respect to the population medians $\left(\theta_{I}, \theta_{N}\right)$, the null hypothesis is $H_{0}: \theta_{I}=\theta_{N}$.

Successively, in order to further delve into the examination of the links between different types of innovation and firm growth, our empirical strategy entails the use of parametric and non-parametric methods illustrated in the three following sections.

\subsection{Quantile Regression Analysis}

As a first step we estimate the following augmented Gibrat's Law equation using Ordinary Least Squares (OLS) and Fixed-Effects (FE) with robust errors using Huber-White sandwich estimator and $\mathrm{QR}$ with boostrapped standard errors ${ }^{7}$ :

$$
G r_{i, t}=\alpha+\beta_{1} \text { Inno }_{i, t-1}+\vec{\lambda} X_{i, t-1}+u_{i, t}
$$

where the dependent variable $G r_{i, t}$ is sales growth of firm $i$ in year $t$, measured as in (1); Inno $_{i, t-1}$ identifies the following variables: InnoProd $_{i, t-1}$ which represents lagged product innovation and InnoProc $i, t-1$ lagged process innovation. Additionally, $X_{i, t-1}$ represents a set of lagged control variables including, among others, firm size and firm age.

It is important to stress the rationale behind the econometric procedures employed in our exercise. Given that sales growth distribution are fat-tailed and skewed (see Figure 1), OLS and FE would produce biased estimates. Instead, the QR approach (Koenker and Bassett Jr, 1978) provides a more robust and efficient estimation method in comparison to OLS and FE

\footnotetext{
${ }^{7}$ In order to check the robustness of the QR estimates, we employed a recent method proposed by Parente and Santos Silva (2016) which allows to obtain standard errors asymptotically valid under heteroskedasticity and misspecification. The estimates are similar whether we estimate the asymptotic covariance matrix or we estimate the covariance matrix by bootstrap. The results are available upon request.
} 
in the presence of outliers and when the error term is not normally distributed (Buchinsky, 1998). Specifically, QR allow to obtain a more detailed picture of the heterogeneous returns to innovation. As a result, our preferred specification will be the QR, while OLS and FE regressions are anyhow presented for completeness.

An important assumption underlying our empirical strategy is that there is a time lag in the growth response due to the introduction of innovations. This conjecture stems from empirical evidence also in the case of Chile (Alvarez et al., 2010). Furthermore, the problem of reverse causality is partially mitigated with the introduction of lagged innovations while growth refers to the successive period. Hence, the effects of successful innovations on firm performance are examined after their introduction over two different time horizons, respectively, two and three years.

Finally, it is important to stress that the estimates presented in the following sections correspond to associations between firms' growth and the different types of innovation rather than estimates of causal effects.

\subsection{PSM and NNM Analysis}

In order to have a richer understanding of the relations examined in our study, we complement the previous analysis by estimating the average treatment effect (ATE) and the average treatment effect on the treated (ATET). In order to do this, we propensity score matching (PSM) and nearest neighbours matching (NNM) estimators following recent contributions analysing innovation and firm performance (Kannebley Jr et al., 2010; Alvarez et al., 2010; Coad et al., 2015). These methods allow to estimate the effect of innovation on sales growth by comparing firms with a similar propensity to introduce innovations.

The PSM consists of two stages: in the first one a logit model for each of the innovation variables is estimated in order to build our counterfactual sample. Conditional on satisfying the balancing property of the propensity score, the fitted values obtained from estimating the logit estimation are used to pair up innovators with non-innovators and those matched pairs are subsequently used to estimate the average treatment effect of innovation on firm growth. The PSM requires that all variables relevant to the probability of receiving treatment may be observed and included in $X$. Moreover, in order to find adequate matches, it is necessary to ensure a sufficient overlap in the characteristics of treated and untreated units. While the last assumption can be easily tested, the first one is difficult to comply with.

The NNM method imputes the missing potential outcome for each subject by using an average of the outcomes of similar subjects that receive the other treatment level. Similarity between subjects is based on a weighted function of the covariates for each observation. NNM technique is non-parametric, hence it requires a large number of observations to get to the true treatment effect vis-á-vis an estimator that imposes a functional form ${ }^{8}$.

For both techniques, the matching procedure between innovators and non-innovators is based on the entire set of control variables discussed in Section 3.3: sectoral dummies, firm size (in terms of employment), firm age, foreign ownership, whether they are part of a business group, share of employees with tertiary education, export intensity, whether they received public subsidies, year dummies and the Herfindahl index.

\footnotetext{
${ }^{8}$ Abadie and Imbens $(2006,2011)$ show that nearest-neighbor matching estimators are not consistent when matching on two or more continuous covariates. Following their contribution we introduce bias-correction to fix this problem Abadie and Imbens (2012).
} 


\subsection{Unconditional Quantile Treatment Effects Analysis}

The matching techniques presented so far estimate the average effects of the introduction of innovation. Since our goal is to take into account the heterogeneity of innovation returns and the structural differentials in firm capabilities which characterize Chilean productive structure, we also estimate unconditional QTE using matching techniques (Firpo, 2007).

This method describes the difference in the quantiles of the outcome variable (firm growth) for innovators and non innovators without reference to the control variables. Indeed, covariates are used only to estimate the propensity score of the probability of introducing an innovation, thus allowing to compare similar firms. Specifically, the propensity-score weighting estimator is obtained non-parametrically by a local logit estimator from $\operatorname{Inno}_{i}$, given $X$ and a constant. Then, the estimator of the QTE parameter is $\hat{\Delta}^{\theta}=\hat{q}_{1}^{\theta}-\hat{q}_{0}^{\theta}$, where for $I \in\{0,1\}$,

$$
\left(\hat{\alpha}, \hat{q}_{I}^{\theta}\right)=\underset{\alpha, q}{\arg \min }\left\{\frac{1}{N} \sum_{i=1}^{N} \hat{\omega}_{i, I} \rho_{\theta}\left(G r_{i, t}-\alpha-q \text { Inno }_{i, t-1}\right)\right\},
$$

where

$$
\hat{\omega}_{i, 1}=\frac{\operatorname{Inno}_{i, t-1}}{\hat{\operatorname{Pr}}\left[\operatorname{Inno}_{i, t-1}=1 \mid X_{i, t-1}\right]} \text { and } \hat{\omega}_{i, 0}=\frac{1-\text { Inno }_{i, t-1}}{1-\hat{\operatorname{Pr}}\left[\text { Inno }_{i, t-1}=1 \mid X_{i, t-1}\right]},
$$

are the weights, and $\hat{\operatorname{Pr}}\left[\operatorname{Inno}_{i, t-1}=1 \mid X_{i, t-1}\right]$ is the nonparametric estimator of the propensity score.

As illustrated by Frölich and Melly (2010), the definition of unconditional QTE does not change when we change the set of covariates $X$. Contrarily, standard QR allows the relationship between the explanatory variable and the dependent variable to vary based on a nonseparable disturbance term labelled "unobserved proneness" for the outcome variable. As covariates are added, some of this unobserved proneness becomes observed and, consequently, the interpretation of the estimates changes. In other words, take the example relating firm growth to firm age. In this case, the unconditional 90th percentile refers to high-growth firms, whereas the 90th percentile conditional on age refers to high-growth firms within each age class, who however may not necessarily be high-growth overall. Therefore, the interpretation of the 90th quantile is different if one considers conditional and unconditional quantiles.

A shortcoming of the unconditional QTE estimator by Firpo (2007) is that it relies on the assumption of exogeneity of the treatment variable. Hence, although QTE should provide more accurate estimates compared with traditional QR, we cannot claim that the results correspond to causal effects.

\section{Results}

As a first step we compare the distributions of growth rates for innovating and non-innovating firms by means of the Fligner-Policello tests (results are displayed in Table 3). We can see that for those firms introducing process innovation the underlying sample distribution is not the same as the one for the firms which do not innovate. Moreover, given that in case of rejection of the null hypothesis, the sign of the FP statistics $(\hat{U})$ tells which of the two group is dominant: a negative (positive) sign means that innovator (non-innovator) firms have a 
higher probability to get higher sales growth rates. We can state that the group of innovators stochastically dominates non-innovator firms. Differently, the test does not reject the null in the case of product innovators implying that there is no difference in the distribution of growth rates for firms that introduced or not introduced that kind of innovation. These results confirm the hint given by descriptive statistics which showed that firms carrying out product innovation experienced almost the same growth than the rest.

Table 3: Two-sample Fligner-Policello robust rank order test

\begin{tabular}{lccccc}
\hline Variable & Obs & Mean & Index of Variability & $\hat{U}$ & 2-Tailed p-value \\
\hline InnoProd $_{t-1}$ No & 2422 & $4.5 \mathrm{e}+02$ & $1.9 \mathrm{e}+08$ & -0.392 & 0.69495 \\
InnoProd $_{t-1}$ Yes & 914 & $1.2 \mathrm{e}+03$ & $4.0 \mathrm{e}+08$ & \\
\hline InnoProc $_{t-1}$ No & 2537 & $3.8 \mathrm{e}+02$ & $1.4 \mathrm{e}+08$ & -2.502 & 0.01235 \\
InnoProc $_{t-1}$ Yes & 799 & $1.3 \mathrm{e}+03$ & $4.3 \mathrm{e}+08$ & & \\
\hline \multicolumn{6}{c}{ Source: Authors' elaboration based on ELE. Growth is defined as in (1). }
\end{tabular}

After testing for whether innovation can be considered a source of growth differentials, we analyze the effects of innovative activities on firm growth using $\mathrm{QR}$ and matching techniques.

\subsection{Quantile Regression Estimates}

In Table 4 we report OLS, FE and QR estimates of eq. (2). First of all, we can observe that according to OLS estimates product innovation is not significantly different from zero. However, process innovation is found to be positively and significantly ( 5 per cent confidence level) related with firm growth. In the FE specification, the point estimate of product innovation is negative and significant at 5 per cent level, while process innovation coefficient is positive but not significant.

However, QR yield quite interesting results. Indeed, we can observe that, while product innovation is not significant, process innovation yields positive and significant results. Although OLS estimates were able to capture the importance of process innovation for the average firm, QR reveal the existence of a U-shaped relation between this type of innovation and subsequent firm growth: the importance of process innovation increases when considering both the lower and upper tails of the growth distribution. This appears to be consistent with the incremental nature of the innovation activity in less developed countries which is more process-oriented than product-oriented as pointed out by several studies (Cassoni and Ramada-Sarasola, 2012; Crespi and Zuniga, 2012).

Concerning the control variables, the QR results for firm size and age are broadly in line with previous contributions which show that smaller and younger firms have higher expected growth rates than older and larger firms (Mansfield, 1962; Coad, 2009). Indeed, the coefficient on lagged size (in terms of employment) is statistically different from zero showing a decreasing association with firm growth. Second, age negatively affects firm growth for the highest quantiles, with a strong significance level, confirming the intuition that younger firms are typically growing more rapidly than older and more mature firms. Third, we observe that export status has a negative and significant coefficient for the lower tail of the distribution. This maybe unexpected, since the literature on micro-empirics of exports suggest that exporters typically reach superior performance than non-exporters. Recall, however, that a similar result is found for Spanish firms in Hölzl (2009) and Bianchini et al. (2016). As in Goedhuys and Veugelers (2012), we do not find tertiary education having a positive and significant impact on firm growth. 
Table 4: OLS, FE and QR - Innovation and Sales Growth

\begin{tabular}{|c|c|c|c|c|c|c|c|}
\hline & $\begin{array}{l}(1) \\
\text { OLS }\end{array}$ & $\begin{array}{l}(2) \\
\mathrm{FE}\end{array}$ & $\begin{array}{l}(3) \\
\text { q10 }\end{array}$ & $\begin{array}{l}(4) \\
\text { q25 }\end{array}$ & $\begin{array}{l}(5) \\
\text { q50 }\end{array}$ & $\begin{array}{l}(6) \\
\text { q75 }\end{array}$ & $\begin{array}{l}(7) \\
\text { q90 }\end{array}$ \\
\hline $\operatorname{InnoProd}_{t-1}$ & $\begin{array}{c}0.013 \\
(0.012)\end{array}$ & $\begin{array}{c}-0.038^{* *} \\
(0.018)\end{array}$ & $\begin{array}{l}-0.037 \\
(0.023)\end{array}$ & $\begin{array}{c}0.001 \\
(0.011)\end{array}$ & $\begin{array}{l}-0.005 \\
(0.007)\end{array}$ & $\begin{array}{l}-0.002 \\
(0.009)\end{array}$ & $\begin{array}{l}-0.022 \\
(0.014)\end{array}$ \\
\hline $\operatorname{InnoProc}_{t-1}$ & $\begin{array}{l}0.025^{* *} \\
(0.012)\end{array}$ & $\begin{array}{c}0.017 \\
(0.018)\end{array}$ & $\begin{array}{c}0.050^{* *} \\
(0.020)\end{array}$ & $\begin{array}{c}0.017 \\
(0.012)\end{array}$ & $\begin{array}{l}0.015^{*} \\
(0.008)\end{array}$ & $\begin{array}{c}0.026^{* * *} \\
(0.010)\end{array}$ & $\begin{array}{c}0.042^{* * *} \\
(0.016)\end{array}$ \\
\hline Employment $_{t-1}$ & $\begin{array}{c}0.002 \\
(0.003)\end{array}$ & $\begin{array}{c}-0.065^{* * * *} \\
(0.013)\end{array}$ & $\begin{array}{c}0.020^{* * *} * \\
(0.005)\end{array}$ & $\begin{array}{c}0.012^{* * *} * \\
(0.003)\end{array}$ & $\begin{array}{c}0.005^{* * *} * \\
(0.002)\end{array}$ & $\begin{array}{l}-0.003 \\
(0.002)\end{array}$ & $\begin{array}{c}-0.011^{* * *} * \\
(0.004)\end{array}$ \\
\hline Age $_{t-1}$ & $\begin{array}{c}-0.025 * * * \\
(0.008)\end{array}$ & $\begin{array}{l}-0.020 \\
(0.023)\end{array}$ & $\begin{array}{c}0.018 \\
(0.016)\end{array}$ & $\begin{array}{c}0.010 \\
(0.008)\end{array}$ & $\begin{array}{c}-0.010^{* *} \\
(0.005)\end{array}$ & $\begin{array}{c}-0.037^{* * *} \\
(0.006)\end{array}$ & $\begin{array}{c}-0.065^{* * *} * \\
(0.011)\end{array}$ \\
\hline Foreign $_{t-1}$ & $\begin{array}{l}-0.003 \\
(0.019)\end{array}$ & $\begin{array}{c}0.011 \\
(0.039)\end{array}$ & $\begin{array}{c}0.004 \\
(0.036)\end{array}$ & $\begin{array}{l}-0.010 \\
(0.021)\end{array}$ & $\begin{array}{c}0.007 \\
(0.013)\end{array}$ & $\begin{array}{c}0.030^{* *} \\
(0.015)\end{array}$ & $\begin{array}{c}0.053^{* *} * \\
(0.025)\end{array}$ \\
\hline Expint $_{t-1}$ & $\begin{array}{l}-0.001^{*} \\
(0.000)\end{array}$ & $\begin{array}{l}-0.001 \\
(0.001)\end{array}$ & $\begin{array}{c}-0.001 * * * \\
(0.001)\end{array}$ & $\begin{array}{c}-0.001^{* *} \\
(0.000)\end{array}$ & $\begin{array}{c}-0.000^{* *} \\
(0.000)\end{array}$ & $\begin{array}{l}-0.000 \\
(0.000)\end{array}$ & $\begin{array}{c}0.001 \\
(0.001)\end{array}$ \\
\hline $\operatorname{Group}_{t-1}$ & $\begin{array}{c}0.009 \\
(0.013)\end{array}$ & $\begin{array}{l}-0.049 \\
(0.032)\end{array}$ & $\begin{array}{l}-0.029 \\
(0.025)\end{array}$ & $\begin{array}{l}-0.023^{*} \\
(0.012)\end{array}$ & $\begin{array}{l}-0.009 \\
(0.008)\end{array}$ & $\begin{array}{c}0.009 \\
(0.010)\end{array}$ & $\begin{array}{c}0.024 \\
(0.016)\end{array}$ \\
\hline $\mathrm{HC}_{t-1}$ & $\begin{array}{l}-0.000 \\
(0.000)\end{array}$ & $\begin{array}{l}-0.001 \\
(0.000)\end{array}$ & $\begin{array}{l}-0.000 \\
(0.000)\end{array}$ & $\begin{array}{c}0.000 \\
(0.000)\end{array}$ & $\begin{array}{c}0.000 \\
(0.000)\end{array}$ & $\begin{array}{c}0.000 \\
(0.000)\end{array}$ & $\begin{array}{l}-0.000 \\
(0.000)\end{array}$ \\
\hline Public $_{t-1}$ & $\begin{array}{c}0.018 \\
(0.011)\end{array}$ & $\begin{array}{c}0.015 \\
(0.020)\end{array}$ & $\begin{array}{l}0.036^{*} \\
(0.020)\end{array}$ & $\begin{array}{c}0.017 \\
(0.011)\end{array}$ & $\begin{array}{l}-0.003 \\
(0.007)\end{array}$ & $\begin{array}{c}0.002 \\
(0.010)\end{array}$ & $\begin{array}{l}-0.003 \\
(0.017)\end{array}$ \\
\hline Herfin $_{t-1}$ & $\begin{array}{c}-0.008 \\
(0.285)\end{array}$ & $\begin{array}{c}-0.147 \\
(0.302)\end{array}$ & $\begin{array}{l}-0.122 \\
(0.620)\end{array}$ & $\begin{array}{l}-0.112 \\
(0.342)\end{array}$ & $\begin{array}{c}0.037 \\
(0.178)\end{array}$ & $\begin{array}{c}0.018 \\
(0.218)\end{array}$ & $\begin{array}{c}-0.647 \\
(0.464)\end{array}$ \\
\hline Constant & $\begin{array}{c}0.036 \\
(0.052)\end{array}$ & $\begin{array}{c}0.360 * * * \\
(0.121)\end{array}$ & $\begin{array}{c}-0.451^{* * *} \\
(0.104)\end{array}$ & $\begin{array}{c}-0.235^{* * *} \\
(0.050)\end{array}$ & $\begin{array}{l}-0.013 \\
(0.033)\end{array}$ & $\begin{array}{c}0.199 * * * \\
(0.044)\end{array}$ & $\begin{array}{c}0.602^{* * *} \\
(0.083)\end{array}$ \\
\hline Observations & 3,336 & 3,336 & 3,336 & 3,336 & 3,336 & 3,336 & 3,336 \\
\hline$R^{2}$ & 0.009 & 0.042 & 0.044 & 0.022 & 0.006 & 0.021 & 0.052 \\
\hline
\end{tabular}

In sum, what we can conclude from the QR estimates is that product innovation does not significantly affect firms performance while process innovation shows a U-shaped relationship with firm growth particularly affecting firms at the lower and upper parts of the distribution.

\subsection{PSM and NNM Estimates}

In order to provide further evidence, we employ matching techniques: firm propensity to innovate is used to match innovating firms with otherwise similar non-innovating firms to evaluate the importance of innovation for firm growth.

In Table 5, we report the ATET and the ATE obtained by PSM and NNM ${ }^{9}$. The ATET confirms previous results concerning the importance of process innovation for subsequent firm growth. Moreover, product innovation has a negative and significant (10 per cent confidence level) impact on subsequent sales growth when we use NNM. The ATE shows

\footnotetext{
${ }^{9}$ As previously mentioned, treatment-effects estimators reweight the observational data in hopes of achieving experimental-like balanced data results. If the reweighting is successful, then the weighted distribution of each covariate should be the same across treatment groups. In such cases, we say that the treatment model "balanced" the covariates. In order to check whether our control groups were balanced we run two diagnostic tests for both PSM and NNM: i) for each covariate we examined the model-adjusted difference in means in the treatment groups and the ratio of variances; ii) we graphed the model-adjusted estimated probability density functions and the box plots of each covariate over treatment levels for the raw data and for the matched sample. When we consider the NNM, the differences in weighted means are negligible (all close to zero), and variance ratios are all near one indicating that matched data appear to be balanced. Likewise, for the NNM, graphical representation of probability density functions and box plots also indicate covariate balance. On the contrary, the PSM performs worse in terms of balancing when checking both the model-adjusted differences and the box plots for each co-variate. Therefore, we consider the NNM to be more accurate estimates since they show a better covariate balance.
} 
similar results compared to the ATET estimates. Although, product innovation is never significant.

Table 5: Average Matching Estimates

\begin{tabular}{|c|c|c|c|c|}
\hline \multicolumn{5}{|c|}{ Average Treatment Effects on the Treated - PSM } \\
\hline Product Innovators & -0.00027 & 0.0159 & -0.02 & 0.986 \\
\hline Process Innovators & $0.02471^{*}$ & 0.0139 & 1.77 & 0.077 \\
\hline \multicolumn{5}{|c|}{ Average Treatment Effects on the Treated - NNM } \\
\hline & Coefficient & AI SE & z & $P>|z|$ \\
\hline Product Innovators & $-0.02491^{*}$ & 0.0151 & -1.65 & 0.099 \\
\hline Process Innovators & $0.03692^{* *}$ & 0.0161 & 2.29 & 0.022 \\
\hline \multicolumn{5}{|c|}{ Average Treatment Effects - PSM } \\
\hline & Coefficient & AI SE & z & $P>|z|$ \\
\hline Product Innovators & -0.007104 & 0.0152 & -0.47 & 0.641 \\
\hline Process Innovators & $0.031042^{*}$ & 0.0184 & 1.68 & 0.092 \\
\hline \multicolumn{5}{|c|}{ Average Treatment Effects - NNM } \\
\hline & Coefficient & AI SE & z & $P>|z|$ \\
\hline Product Innovators & -0.02083 & 0.0147 & -1.41 & 0.157 \\
\hline Process Innovators & $0.05295 * * *$ & 0.0157 & 3.36 & 0.001 \\
\hline
\end{tabular}

Notes: ***, ** and * indicate significance on a $1 \%, 5 \%$ and $10 \%$ level, respectively. Estimates for the NNM are obtained using the Abadie and Imbens $(2006,2011)$ bias-corrected estimator for robust standard errors (AI $\mathrm{SE})$. Treatment variables are innovation dummies. The selection of the control group is based on the entire set of control variables discussed in Section 3.3: sectoral dummies, firm size (in terms of employment), firm age, foreign ownership, whether they are part of a business group, share of employees with tertiary education, export intensity, whether they received public subsidies, the Herfindahl index and year dummies. $N=3341,1$ minimum required match for NNM estimates and 2 minimum required matches for PSM estimates.

\subsection{Unconditional QTE Estimates}

In Table 6, we complement the matching analysis on the average effects with QTE in order to examine the heterogeneity of innovation returns to firm growth. This method allows for a more accurate assessment of the relation under study since it compares similar firms in terms of their probability of introducing innovation and estimate these effects taking into account the unconditional distribution of the outcome variable (i.e. sales growth). The results largely confirm the importance of process innovation, while product innovation is negatively and significantly (10 per cent confidence level) associated with firm growth for the highest quantile of the distribution. However, in contrast with traditional QR estimates, we do not find the same U-shaped relation between process innovation and firm growth. Indeed, process innovation seems to significantly and positively affect only fast-growing firms (75th and 90th percentiles). Moreover, the patterns of significance and point estimates indicate that process innovation appear to have a stronger relevance at the 75 th percentile than at the 90 th percentile. 
Table 6: Unconditional Quantile Treatment Effect Estimates

\begin{tabular}{cccccc}
\hline & $\mathrm{q} 10$ & $\mathrm{q} 25$ & $\mathrm{q} 50$ & $\mathrm{q} 75$ & $\mathrm{q} 90$ \\
\hline Product Innovators & -0.0067 & 0.0074 & -0.0042 & -0.0132 & $-0.0356^{*}$ \\
& $(0.0316)$ & $(0.0138)$ & $(0.0084)$ & $(0.0111)$ & $(0.0178)$ \\
Process Innovators & 0.0138 & 0.0215 & 0.01826 & $0.0492^{* *}$ & $0.0433^{*}$ \\
& $(0.0269)$ & $(0.0191)$ & $(0.0120)$ & $(0.0167)$ & $(0.0241)$
\end{tabular}

Notes: Standard errors in parenthesis. $* * *, * *$ and $*$ indicate significance on a $1 \%, 5 \%$ and $10 \%$ level, respectively. The first-step regression to calculate the propensity score is obtained using ivqte while unconditional QTE are obtained with the STATA command ivqte both developed by Frölich and Melly (2010). The selection of the control group is based on the entire set of control variables discussed in Section 3.3: sectoral dummies, firm size (in terms of employment), firm age, foreign ownership, whether they are part of a business group, share of employees with tertiary education, export intensity, whether they received public subsidies, the Herfindahl index and year dummies. $N=3341$.

\section{Discussion}

The results presented in the previous section confirm the importance of adopting estimation methods that take into account the heterogeneity of firms' performance. Indeed, firms' sales growth is typically characterized by heavier tails than the Gaussian distribution. Moreover, accounting for the heterogeneity of the returns to innovation is especially relevant when considering Latin American countries since the productive structures are characterized by significant structural differentials among firm sizes and within and between sectors (Catela et al., 2015). Thus, QR techniques provide a more suited alternative to OLS and FE given the properties of the data. According to these estimates, we see that process innovation shows a U-shaped relation with firm growth, affecting especially the lowest and the highest percentiles.

However, we argue that it is crucial to obtain estimates of the innovation effects by comparing similar firms in such a way that the only difference among them will be the successful introduction of innovation. Hence, we choose the unconditional QTE under exogeneity (Firpo, 2007; Frölich and Melly, 2010) as our preferred method. Indeed, the estimates deriving from QR may come from the comparison of very different firms. Contrarily, the unconditional QTE approach allows to estimate the effects of introducing an innovation based on the comparison between similar firms using matching techniques.

The results based on the QTE approach do show important differences if compared with standard QR. On one hand, the U-shaped relation of process innovation and firm growth disappears: process innovation positively affects only fast-growing firms. On the other, product innovation turns up to be significantly and negatively associated with firm growth for those business located at the 90th percentile.

The lack of positive association between product innovation and firm growth, although at odds with theoretical expectations, is not an unprecedented finding in literature. Indeed, studies such as Hölzl (2009), Kannebley Jr et al. (2010), Hölzl and Friesenbichler (2010) do not find evidence of product innovators necessarily performing better than non-product innovators or they even find a negative relation (Freel and Robson, 2004). In particular, our contribution is in line with those studies which do not show a significant association for product innovation in emerging countries (Kannebley Jr et al., 2010), or those taking into consideration countries which are distant to the technological frontier (Hölzl, 2009; Hölzl and Friesenbichler, 2010; Damijan et al., 2012). Indeed, innovation expenditures in less developed countries generally focus on the acquisition of foreign machinery and equipment that embody newer vintage of technology (which relates to process innovation) rather than 
on strong R\&D in-house capabilities (which relate more with product innovation) (Vivarelli, 2014).

Nonetheless, we can point at three additional explanations regarding the results on product innovation. First, as previously highlighted, this might be related with the way we measure this innovation activity: indeed, the ELE does not provide any additional information regarding the 'quality' of product innovation or its share on firm's turnover. In fact, previous studies have highlighted the importance of taking into account the degree of novelty of product innovation when assessing its effect on sales growth (Duguet, 2006; Kannebley Jr et al., 2010; Cucculelli and Ermini, 2012; Bianchini et al., 2016). Therefore, our imperfect measure of product innovation might fail to isolate those 'radical' innovations which might be more beneficial in terms of firm performance since they do not refer to previously existing products and because no competitor produces it (Duguet, 2006).

Second, we should bear in mind that in less developed countries, the very nature of innovation differs from developed economies. While in the latter the introduction of a new product usually means placing it on the international market, in less developed countries the degree of novelty generally extends only to domestic markets since the underlying innovations are the result of technology transfers and adoption from abroad (Hall and Mairesse, 2006; Bogliacino et al., 2009).

These considerations are especially relevant in the case of Chile. Indeed, the limited efforts in improving domestic technological capabilities by the private sector affect the degree of novelty of the innovations commercialized by Chilean firms: when compared with other Latin American countries, Chile has one of the lowest shares in terms of new-to-the-world product innovations while the bulk refers to new-to-the-firm products (Casanova et al., 2011).

Third, we cannot rule out the possibility that our results could be partly driven by the 2008-2009 global crisis although Latin American countries and Chile were less affected than others and GDP recovered already in $2010^{10}$. Indeed, innovative efforts tend to be procyclical and decrease significantly during recessions (Paunov, 2012) motivated by low demand expectations. Therefore, a possible explanation for our results is that firms engaged less intensively in product innovation projects because of weak demand expectations for their products and dedicated more effort to achieve efficiency improvements through process innovation.

\section{Conclusions}

In summary, this article sought to investigate the relationship between innovation (in both products and processes) and subsequent firm performance in terms of sales growth employing a sample representative of the Chilean productive structure. To this end, the most relevant findings highlight a positive relationship between process innovation and growth for those firms located at the upper-tail of the firm growth distribution. Moreover, we find a negative relationship between product innovation and growth in sales only for high-growth firms while this innovation activity is not significant for the rest of the distribution. Overall, the results confirm that innovation as a highly uncertain activity, with the returns to innovation being remarkably heterogeneous with some firms benefiting more than others (Coad, 2009).

The study is bound by several limitations. First, innovation processes are captured by imperfect measures. For instance, it would be interesting to investigate the relation between

\footnotetext{
${ }^{10}$ See Paunov (2012) on the impact of the crisis on innovation activities in Latin American firms.
} 
firm growth and the novelty of the innovations introduced by Chilean firms as this could shed more light on the object of analysis. Second, we cannot rule out potential endogeneity bias in our estimates although the lag structure should mitigate this problem.

Future research should investigate whether the persistence in innovating behaviour and the combination of different types of innovation have a larger impact on subsequent firms' performances. Indeed, Damanpour et al. (2009) suggest that combinations of different types of innovations may have a larger impact on firms performances. Moreover, one could test the hypothesis according to which firms benefit from their innovations through increased price-cost margins (Cohen and Klepper, 1996) or profit margins (Geroski and Machin, 1992) rather than higher sales growth. Finally, by employing panel data featuring a longer time span such as the Chilean manufacturing survey (ENIA), it would be possible to investigate the heterogeneity of the impacts of the successful introduction of product innovation on the conditional distribution of firm growth rates using a Fixed-Effects Panel Quantile Regression approach (Canay, 2011).

\section{References}

Abadie, A. and G. Imbens (2012). Matching on the estimated propensity score. harvard university and national bureau of economic research.

Aghion, P. and P. Howitt (2005). Growth with quality-improving innovations: an integrated framework. Handbook of economic growth 1, 67-110.

Alvarez, R., J. M. Benavente, R. Campusano, and C. Cuevas (2011). Employment generation, firm size, and innovation in chile. Technical report, Inter-American Development Bank.

Alvarez, R., C. Bravo-Ortega, and L. Navarro (2010). Innovation, r\&d investment and productivity in chile.

Álvarez, R. and G. A. Crespi (2015). Heterogeneous effects of financial constraints on innovation: Evidence from chile. Science and Public Policy, scu091.

Alvarez, R., A. Zahler, and C. Bravo Ortega (2012). Innovation and productivity in services: Evidence from chile. Technical report, Inter-American Development Bank.

Audretsch, D. B., A. Coad, and A. Segarra (2014). Firm growth and innovation. Small Business Economics 43(4), 743-749.

Bartelsman, E., S. Dobbelaere, and B. Peters (2014). Allocation of human capital and innovation at the frontier: Firm-level evidence on germany and the netherlands. Industrial and Corporate Change, dtu038.

Benavente, J. M. (2006). The role of research and innovation in promoting productivity in chile. Economics of Innovation and New Technology 15(4-5), 301-315.

Benavente, J. M. and R. Lauterbach (2008). Technological innovation and employment: complements or substitutes? The European Journal of Development Research 20(2), 318-329.

Bianchini, S., G. Pellegrino, and F. Tamagni (2016). Innovation strategies and firm growth: New longitudinal evidence from spanish firms. LEM Working Paper, Sant'Anna School of Advanced Studies, Pisa, Italy.

Birch, D. G. (1987). Job creation in america: How our smallest companies put the most people to work. University of Illinois at Urbana-Champaign's Academy for Entrepreneurial Leadership Historical Research Reference in Entrepreneurship.

Bogliacino, F., G. Perani, M. Pianta, and S. Supino (2009). Innovation in developing countries. the evidence from innovation surveys. In FIRB conference Research and Entrepreneurship in the Knowledge-based Economy, Milano: Universita L. Bocconi. 
Bottazzi, G., G. Dosi, M. Lippi, F. Pammolli, and M. Riccaboni (2001). Innovation and corporate growth in the evolution of the drug industry. International Journal of Industrial Organization 19(7), 1161-1187.

Bottazzi, G. and A. Secchi (2006). Explaining the distribution of firm growth rates. Rand Journal of Economics, 235-256.

Bottazzi, G. and A. Secchi (2011). A new class of asymmetric exponential power densities with applications to economics and finance. Industrial and Corporate Change, dtr036.

Buchinsky, M. (1998). Recent advances in quantile regression models: a practical guideline for empirical research. Journal of human resources, 88-126.

Canay, I. A. (2011). A simple approach to quantile regression for panel data. The Econometrics Journal 14(3), 368-386.

Casanova, L., F. Castellucci, J. Dayton-Johnson, S. Dutta, N. Fonstad, C. Paunov, and M. Pezzini (2011). Innovalatino: fostering innovation in latin america. insead.

Cassoni, A. and M. Ramada-Sarasola (2012). The returns to innovation in latin america: inexistent or mismeasured? Latin American Business Review 13(2), 141-169.

Catela, E. Y., M. Cimoli, and G. Porcile (2015). Productivity and structural heterogeneity in the brazilian manufacturing sector: trends and determinants. Oxford Development Studies (ahead-of-print), 1-21.

Chudnovsky, D., A. López, and G. Pupato (2006). Innovation and productivity in developing countries: A study of argentine manufacturing firms behavior (1992-2001). Research policy 35(2), 266-288.

Cimoli, M. et al. (2005). Heterogeneidad estructural, asimetrías tecnológicas y crecimiento en américa latina.

Cirillo, V. (2014). Patterns of innovation and wage distribution. do "innovative firms" pay higher wages? evidence from chile. Eurasian Business Review 4(2), 181-206.

Coad, A. (2009). The growth of firms: A survey of theories and empirical evidence. Edward Elgar Publishing.

Coad, A., G. Pellegrino, and M. Savona (2015). Barriers to innovation and firm productivity. Economics of Innovation and New Technology, 1-14.

Coad, A. and R. Rao (2008). Innovation and firm growth in high-tech sectors: A quantile regression approach. Research Policy 37(4), 633-648.

Coad, A., A. Segarra, and M. Teruel (2013). Like milk or wine: Does firm performance improve with age? Structural Change and Economic Dynamics 24, 173-189.

Cohen, W. M. and S. Klepper (1996). A reprise of size and r\&d. The Economic Journal, 925-951.

Colombelli, A., N. Haned, and C. Le Bas (2013). On firm growth and innovation: Some new empirical perspectives using french cis (1992-2004). Structural Change and Economic Dynamics 26, 14-26.

Cozza, C., F. Malerba, M. L. Mancusi, G. Perani, and A. Vezzulli (2012). Innovation, profitability and growth in medium and high-tech manufacturing industries: evidence from italy. Applied Economics 44(15), $1963-1976$.

Crépon, B., E. Duguet, and J. Mairessec (1998). Research, innovation and productivity: An econometric analysis at the firm level. Economics of Innovation and new Technology 7(2), 115-158.

Crespi, G. and P. Zuniga (2012). Innovation and productivity: evidence from six latin american countries. World Development 40(2), 273-290.

Cucculelli, M. and B. Ermini (2012). New product introduction and product tenure: What effects on firm growth? Research Policy 41(5), 808-821.

Damanpour, F., R. M. Walker, and C. N. Avellaneda (2009). Combinative effects of innovation types and organizational performance: A longitudinal study of service organizations. Journal of Management Studies 46(4), 650-675. 
Damijan, J. P., Č. Kostevc, and M. Rojec (2012). Does innovation help the good or the poor performing firms? Economics Letters 115(2), 190-195.

Delmar, F., P. Davidsson, and W. B. Gartner (2003). Arriving at the high-growth firm. Journal of business venturing 18(2), 189-216.

Duguet, E. (2006). Innovation height, spillovers and tfp growth at the firm level: Evidence from french manufacturing. Economics of Innovation and New Technology 15(4-5), 415-442.

Ericson, R. and A. Pakes (1995). Markov-perfect industry dynamics: A framework for empirical work. The Review of Economic Studies 62(1), 53-82.

Eurostat (2013). Seventh community innovation survey. Available online at http://ec.europa.eu/ eurostat/web/science-technology-innovation/data/database.

Falk, M. (2012). Quantile estimates of the impact of r\&d intensity on firm performance. Small Business Economics 39(1), 19-37.

Firpo, S. (2007). Efficient semiparametric estimation of quantile treatment effects. Econometrica, 259-276.

Fligner, M. A. and G. E. Policello (1981). Robust rank procedures for the behrens-fisher problem. Journal of the American Statistical Association 76(373), 162-168.

Freel, M. S. and P. J. Robson (2004). Small firm innovation, growth and performance evidence from scotland and northern england. International Small Business Journal 22(6), 561-575.

Frölich, M. and B. Melly (2010). Estimation of quantile treatment effects with stata. Stata Journal 10(3), 423.

Geroski, P. (2002). The growth of firms in theory and in prattice. Competence, governance and entrepreneurship 1, 168-186.

Geroski, P. and S. Machin (1992). Do innovating firms outperform non-innovators?*. Business Strategy Review 3(2), 79-90.

Geroski, P. A. (1995). What do we know about entry? International Journal of Industrial Organization 13(4), 421-440.

Geroski, P. A., J. Van Reenen, and C. F. Walters (1997). How persistently do firms innovate? Research Policy 26(1), 33-48.

Gibrat, R. (1931). Les inégalités économiques. Recueil Sirey.

Goedhuys, M. and L. Sleuwaegen (2010). High-growth entrepreneurial firms in africa: a quantile regression approach. Small Business Economics 34(1), 31-51.

Goedhuys, M. and L. Sleuwaegen (2016). High-growth versus declining firms: the differential impact of human capital and r\&d. Applied Economics Letters 23(5), 369-372.

Goedhuys, M. and R. Veugelers (2012). Innovation strategies, process and product innovations and growth: Firm-level evidence from brazil. Structural Change and Economic Dynamics 23(4), 516-529.

Hall, B. H. and J. Mairesse (2006). Empirical studies of innovation in the knowledge-driven economy. Economics of Innovation and New Technology 15(4-5), 289-299.

Haltiwanger, J., R. S. Jarmin, and J. Miranda (2013). Who creates jobs? small versus large versus young. Review of Economics and Statistics 95(2), 347-361.

Hölzl, W. (2009). Is the r\&d behaviour of fast-growing smes different? evidence from cis iii data for 16 countries. Small Business Economics 33(1), 59-75.

Hölzl, W. and K. S. Friesenbichler (2010). High-growth firms, innovation and the distance to the frontier. Economics Bulletin 30(2), 1016-1024. 
Jovanovic, B. (1982). Selection and the evolution of industry. Econometrica: Journal of the Econometric Society, 649-670.

Kannebley Jr, S., J. V. Sekkel, and B. C. Araújo (2010). Economic performance of brazilian manufacturing firms: a counterfactual analysis of innovation impacts. Small Business Economics 34 (3), 339-353.

Koenker, R. and G. Bassett Jr (1978). Regression quantiles. Econometrica: journal of the Econometric Society, 33-50.

Lever, M. and H. Nieuwenhuijsen (1999). The impact of competition on productivity in dutch manufacturing. Innovation, Industry Evolution and Employment, 111-128.

Mairesse, J. and P. Mohnen (2010). Using innovation surveys for econometric analysis. Handbook of the Economics of Innovation 2, 1129-1155.

Mansfield, E. (1962). Entry, gibrat's law, innovation, and the growth of firms. The American Economic Review, 1023-1051.

Mazzucato, M. and S. Parris (2015). High-growth firms in changing competitive environments: the us pharmaceutical industry (1963 to 2002). Small Business Economics 44(1), 145-170.

Ministerio de Economia (2014). Octava encuesta de innovacion en empresas, 2011-2012. principales resultados. Available online at http://www.economia.gob.cl/wp-content/uploads/2014/02/ Presentacion-Resultados-8va-Encuesta-Innovacion1.pdf.

Moreno, F. and A. Coad (2015). High-growth firms: Stylized facts and conflicting results. Technical report, SPRU-Science and Technology Policy Research, University of Sussex.

Nelson, R. R. and S. Winter (1982). An evolutionary theory of economic change. An evolutionary theory of economic change.

Nickell, S. J. (1996). Competition and corporate performance. Journal of political economy, 724-746.

OECD (2005). Oslo manual: Guidelines for collecting and interpreting innovation data. Number 4. Publications de l'OCDE.

OECD/ECLAC (2013). Latin american economic outlook 2013.

OECD/World Bank (2015). The innovation policy platform. Available online at http://www. innovationpolicyplatform.org/content/statistics-ipp.

Parente, P. M. and J. Santos Silva (2016). Quantile regression with clustered data. Journal of Econometric Methods 5(1), 1-15.

Paunov, C. (2012). The global crisis and firms investments in innovation. Research Policy 41(1), 24-35.

Pavitt, K. (1984). Sectoral patterns of technical change: towards a taxonomy and a theory. Research policy 13(6), 343-373.

Pérez, P., G. Dutrénit, and F. Barceinas (2005). Actividad innovadora y desempeño económico: un análisis econométrico del caso mexicano. Indicadores de Ciencia y Tecnología en Iberoamérica. Buenos Aires, Argentina: RICYT.

Pinto, A. (1970). Naturaleza e implicaciones de la" heterogeneidad estructural" de la américa latina. El trimestre económico, 83-100.

Raffo, J., S. Lhuillery, and L. Miotti (2008). Northern and southern innovativity: a comparison across european and latin american countries. The European Journal of Development Research 20(2), 219-239.

Santoleri, P. (2015). Diversity and intensity of information and communication technologies use and product innovation: evidence from chilean micro-data. Economics of Innovation and New Technology 24(6), 550568.

Santoleri, P. and G. Stumpo (2011). Microempresas y pymes en amrica latina: Caractersticas de las firmas y polticas de apoyo. Documento de trabajo, Divisin de Desarrollo Productivo y Empresarial. 
Sunkel, O. (1978). La dependencia y la heterogeneidad estructural. El trimestre económico, 3-20.

Vivarelli, M. (2014). Innovation, employment and skills in advanced and developing countries: a survey of economic literature. Journal of Economic Issues 48(1), 123-154.

\section{Appendix}

Table 7: Sample distribution by industry and size

\begin{tabular}{lccccc}
\hline & Micro & Small & Medium & Large & Sample \% (N) \\
\hline Agriculture & 1.25 & 1.90 & 5.32 & 1.86 & 2.55 \\
Mining & 1.25 & 3.02 & 5.17 & 2.92 & 3.30 \\
Manufacturing & 15.42 & 14.54 & 12.36 & 17.07 & 15.29 \\
Retail & 25.66 & 19.35 & 13.65 & 25.17 & 9.29 \\
Transportation & 8.33 & 10.96 & 10.63 & 9.03 & 11.33 \\
Real Estate & 12.67 & 14.53 & 10.20 & 10.49 & 10.49 \\
Construction & 10.83 & 11.19 & 8.19 & 11.09 & 10.19 \\
Electricity & 0 & 0 & 3.74 & 5.51 & 4.38 \\
Hotel & 16.67 & 15.88 & 12.07 & 4.91 & 6.44 \\
Finance & 0 & 0 & 5.60 & 7.10 & $100(3336)$ \\
Other services & 7.92 & 7.94 & 7.47 & 4.85 & \\
\hline Sample \% (N) & $7.19(240)$ & $26.80(894)$ & $20.86(696)$ & $45.14(1,506)$ & 100
\end{tabular}

Source: Authors' elaboration based on ELE.

Table 8: Summary Statistics and Variable Description

\begin{tabular}{|c|c|c|c|c|c|c|}
\hline Variable & Description & Mean & SD & Min. & Max. & $\mathbf{N}$ \\
\hline Sales_gr & Average annual firm growth (eq.1) & 0.023 & 0.276 & -3.145 & 1.181 & 3336 \\
\hline Sales_corr & Average annual firm growth (eq.5) & 0.032 & 0.263 & -1.597 & 1.333 & 3336 \\
\hline InnoProd & $=1$ if firm introduced new or improved good or service $(0 / 1)$ & 0.274 & 0.446 & 0 & 1 & 3336 \\
\hline InnoProc & $=1$ if firm introduced a process innovation $(0 / 1)$ & 0.24 & 0.427 & 0 & 1 & 3336 \\
\hline Foreign & $=1$ if firm is at least partly owned by foreign capital & 0.09 & 0.287 & 0 & 1 & 3336 \\
\hline Expint & Exports over total sales (\%) & 4.881 & 17.837 & 0 & 100 & 3336 \\
\hline Group & $=1$ if firm is a part of a business group $(0 / 1)$ & 0.277 & 0.448 & 0 & 1 & 3336 \\
\hline Employment & Number of employees (log) & 3.669 & 2.1 & 0 & 11.124 & 3336 \\
\hline Age & Firm's age (log) & 2.593 & 0.712 & 0 & 5.043 & 3336 \\
\hline Herfin & Sum of the squared market share of each firm at the sector level & 0.093 & 0.08 & 0.026 & 0.397 & 3336 \\
\hline Public & $=1$ if firm received public support $(0 / 1)$ & 0.182 & 0.386 & 0 & 1 & 3336 \\
\hline $\mathrm{HC}$ & Employees with tertiary education over total employees (\%) & 17.647 & 25.66 & 0 & 100 & 3336 \\
\hline
\end{tabular}


Table 9: Pair-wise correlation matrix

\begin{tabular}{|c|c|c|c|c|c|c|}
\hline Variables & Sales_gr & Sales_corr & InnoProd $_{t-1}$ & InnoProc $_{t-1}$ & Foreign $_{t-1}$ & Expint $_{t-1}$ \\
\hline Sales_gr & 1.000 & & & & & \\
\hline Sales_corr & $\begin{array}{l}0.989 \\
(0.000)\end{array}$ & 1.000 & & & & \\
\hline $\operatorname{InnoProd}_{t-1}$ & $\begin{array}{l}-0.004 \\
(0.806)\end{array}$ & $\begin{array}{l}-0.007 \\
(0.667)\end{array}$ & 1.000 & & & \\
\hline $\operatorname{InnoProc}_{t-1}$ & $\begin{array}{c}0.030 \\
(0.082)\end{array}$ & $\begin{array}{l}0.028 \\
(0.104)\end{array}$ & $\begin{array}{c}0.377 \\
(0.000)\end{array}$ & 1.000 & & \\
\hline Foreign $_{t-1}$ & $\begin{array}{l}-0.006 \\
(0.724)\end{array}$ & $\begin{array}{l}-0.006 \\
(0.737)\end{array}$ & $\begin{array}{c}0.076 \\
(0.000)\end{array}$ & $\begin{array}{c}0.086 \\
(0.000)\end{array}$ & 1.000 & \\
\hline $\operatorname{Expint}_{t-1}$ & $\begin{array}{l}-0.032 \\
(0.062)\end{array}$ & $\begin{array}{l}-0.031 \\
(0.069)\end{array}$ & $\begin{array}{c}0.056 \\
(0.001)\end{array}$ & $\begin{array}{c}0.065 \\
(0.000)\end{array}$ & $\begin{array}{c}0.164 \\
(0.000)\end{array}$ & 1.000 \\
\hline $\operatorname{Group}_{t-1}$ & $\begin{array}{c}0.019 \\
(0.285)\end{array}$ & $\begin{array}{c}0.017 \\
(0.339)\end{array}$ & $\begin{array}{c}0.141 \\
(0.000)\end{array}$ & $\begin{array}{c}0.185 \\
(0.000)\end{array}$ & $\begin{array}{c}0.282 \\
(0.000)\end{array}$ & $\begin{array}{l}0.137 \\
(0.000)\end{array}$ \\
\hline Employment $_{t-1}$ & $\begin{array}{c}0.010 \\
(0.548)\end{array}$ & $\begin{array}{c}0.001 \\
(0.953)\end{array}$ & $\begin{array}{c}0.215 \\
(0.000)\end{array}$ & $\begin{array}{l}0.286 \\
(0.000)\end{array}$ & $\begin{array}{c}0.238 \\
(0.000)\end{array}$ & $\begin{array}{c}0.179 \\
(0.000)\end{array}$ \\
\hline $\mathrm{Age}_{t-1}$ & $\begin{array}{l}-0.051 \\
(0.003)\end{array}$ & $\begin{array}{l}-0.061 \\
(0.000)\end{array}$ & $\begin{array}{c}0.096 \\
(0.000)\end{array}$ & $\begin{array}{l}0.101 \\
(0.000)\end{array}$ & $\begin{array}{l}0.067 \\
(0.000)\end{array}$ & $\begin{array}{l}0.033 \\
(0.056)\end{array}$ \\
\hline $\mathrm{HC}_{t-1}$ & $\begin{array}{l}-0.007 \\
(0.701)\end{array}$ & $\begin{array}{l}-0.005 \\
(0.768)\end{array}$ & $\begin{array}{c}0.068 \\
(0.000)\end{array}$ & $\begin{array}{l}0.045 \\
(0.010)\end{array}$ & $\begin{array}{c}0.211 \\
(0.000)\end{array}$ & $\begin{array}{l}0.056 \\
(0.001)\end{array}$ \\
\hline Public $_{t-1}$ & $\begin{array}{c}0.024 \\
(0.159)\end{array}$ & $\begin{array}{c}0.020 \\
(0.250)\end{array}$ & $\begin{array}{c}0.120 \\
(0.000)\end{array}$ & $\begin{array}{c}0.186 \\
(0.000)\end{array}$ & $\begin{array}{c}0.082 \\
(0.000)\end{array}$ & $\begin{array}{l}0.116 \\
(0.000)\end{array}$ \\
\hline $\operatorname{Herfin}_{t-1}$ & $\begin{array}{c}0.000 \\
(0.996)\end{array}$ & $\begin{array}{l}-0.004 \\
(0.806)\end{array}$ & $\begin{array}{c}0.107 \\
(0.000)\end{array}$ & $\begin{array}{c}0.065 \\
(0.000)\end{array}$ & $\begin{array}{c}0.040 \\
(0.021)\end{array}$ & $\begin{array}{c}0.150 \\
(0.000)\end{array}$ \\
\hline Variables & $\operatorname{Group}_{t-1}$ & Employment $_{t-1}$ & Age $_{t-1}$ & $\mathrm{HC}_{t-1}$ & Public $_{t-1}$ & $\operatorname{Herfin}_{t-1}$ \\
\hline $\operatorname{Group}_{t-1}$ & $\begin{array}{c}1.000 \\
(0.000)\end{array}$ & & & & & \\
\hline Employment $_{t-1}$ & $\begin{array}{c}0.412 \\
(0.000)\end{array}$ & $\begin{array}{c}1.000 \\
(0.000)\end{array}$ & & & & \\
\hline Age $_{t-1}$ & $\begin{array}{c}0.109 \\
(0.056)\end{array}$ & $\begin{array}{c}0.284 \\
(0.000)\end{array}$ & $\begin{array}{c}1.000 \\
(0.000)\end{array}$ & & & \\
\hline $\mathrm{HC}_{t-1}$ & $\begin{array}{c}0.234 \\
(0.001)\end{array}$ & $\begin{array}{c}0.037 \\
(0.000)\end{array}$ & $\begin{array}{c}0.020 \\
(0.034)\end{array}$ & $\begin{array}{l}1.000 \\
(0.251)\end{array}$ & & \\
\hline Public $_{t-1}$ & $\begin{array}{c}0.207 \\
(0.000)\end{array}$ & $\begin{array}{c}0.324 \\
(0.000)\end{array}$ & $\begin{array}{c}0.120 \\
(0.000)\end{array}$ & $\begin{array}{c}0.082 \\
(0.000)\end{array}$ & $\begin{array}{c}1.000 \\
(0.000)\end{array}$ & \\
\hline $\operatorname{Herfin}_{t-1}$ & $\begin{array}{c}0.012 \\
(0.000)\end{array}$ & $\begin{array}{c}0.072 \\
(0.471)\end{array}$ & $\begin{array}{c}0.078 \\
(0.000)\end{array}$ & $\begin{array}{l}-0.104 \\
(0.000)\end{array}$ & $\begin{array}{c}0.077 \\
(0.000)\end{array}$ & $\begin{array}{c}1.000 \\
(0.000)\end{array}$ \\
\hline
\end{tabular}

\subsection{Robustness Check}

In this section we present some additional estimates in order to check the robustness of the results showed in Section 5.1. As Audretsch et al. (2014) pointed out, the indicators used to measure growth are not neutral with respect to empirical results. Different measures describe different patterns of growth (Delmar et al., 2003). For this reason, we introduce an alternative growth rate measure to conduct a robustness check. Following Birch (1987) and Schreyer (2000), we use an index that helps reduce the bias toward larger firms (absolute growth) and small firms (relative growth rate). Proportional growth is biased towards small firms, as small units are much more likely to exhibit high rates of proportional growth than large firms. Absolute growth is the absolute change in size. Measuring growth in absolute or relative terms can lead to different results (Audretsch et al., 2014; Hölzl and Friesenbichler, 2010; Delmar et al., 2003). The index used is a simple combination of proportional and absolute growth (Coad, 2009; Hölzl and Friesenbichler, 2010):

$$
G r_{i, t}=\frac{\left(\ln \left(S_{i, t}\right)-\ln \left(S_{i, t-d}\right)\right) \cdot \frac{\ln \left(S_{i, t}\right)}{\ln \left(S_{i, t-d}\right)}}{d}
$$

This measure is still dependent on firm size, but has a smaller bias toward firm size if compared with proportional or absolute measures of growth.

As a first step, we also check the Fligner-Policello test using this alternative growth rate measure and results do not change.

Successively, we estimate the models presented in Section 5.1 employing (5) as our dependent variable. Results are shown in Tables 11, 12 and 13. We can observe that, with 
Table 10: Two-sample Fligner-Policello robust rank order test

\begin{tabular}{lccccc}
\hline Variable & Obs & Mean & Index of Variability & $\hat{U}$ & 2-Tailed p-value \\
\hline InnoProd $_{t-1}$ No & 2422 & $4.5 \mathrm{e}+02$ & $1.9 \mathrm{e}+08$ & -0.383 & 0.70180 \\
InnoProd $_{t-1}$ Yes & 914 & $1.2 \mathrm{e}+03$ & $4.0 \mathrm{e}+08$ & & \\
\hline InnoProc $_{t-1}$ No & 2537 & $3.8 \mathrm{e}+02$ & $1.4 \mathrm{e}+08$ & -2.471 & 0.01348 \\
InnoProc $_{t-1}$ Yes & 799 & $1.3 \mathrm{e}+03$ & $4.3 \mathrm{e}+08$ & & \\
\hline
\end{tabular}

Source: Authors' elaboration based on ELE. Growth is defined as in (5).

respect to the innovation variables, we do not appreciate any significant change. Indeed, point estimates and patterns of significance show little variation compared to the estimates obtained using (5).

Table 11: OLS, FE and QR - Innovation and Sales Growth

\begin{tabular}{|c|c|c|c|c|c|c|c|}
\hline & $\begin{array}{l}(1) \\
\text { OLS }\end{array}$ & $\begin{array}{l}(2) \\
\text { FE }\end{array}$ & $\begin{array}{l}(3) \\
\text { q10 }\end{array}$ & $\begin{array}{l}(4) \\
\mathrm{q} 25\end{array}$ & $\begin{array}{l}(5) \\
\text { q50 }\end{array}$ & $\begin{array}{l}(6) \\
\text { q75 }\end{array}$ & $\begin{array}{l}(7) \\
\text { q90 }\end{array}$ \\
\hline $\operatorname{InnoProd}_{t-1}$ & $\begin{array}{l}-0.013 \\
(0.011)\end{array}$ & $\begin{array}{c}-0.039^{* *} \\
(0.017)\end{array}$ & $\begin{array}{l}-0.033 \\
(0.022)\end{array}$ & $\begin{array}{c}0.002 \\
(0.011)\end{array}$ & $\begin{array}{l}-0.005 \\
(0.007)\end{array}$ & $\begin{array}{l}-0.002 \\
(0.009)\end{array}$ & $\begin{array}{l}-0.023 \\
(0.015)\end{array}$ \\
\hline InnoProc $_{t-1}$ & $\begin{array}{c}0.026^{* *} \\
(0.012)\end{array}$ & $\begin{array}{c}0.015 \\
(0.017)\end{array}$ & $\begin{array}{c}0.047^{* *} \\
(0.019)\end{array}$ & $\begin{array}{c}0.017 \\
(0.012)\end{array}$ & $\begin{array}{l}0.015^{*} \\
(0.008)\end{array}$ & $\begin{array}{c}0.027^{* *} \\
(0.010)\end{array}$ & $\begin{array}{c}0.045^{* * * *} \\
(0.017)\end{array}$ \\
\hline Employment $_{t-1}$ & $\begin{array}{c}0.000 \\
(0.003)\end{array}$ & $\begin{array}{c}-0.065^{* * *} \\
(0.013)\end{array}$ & $\begin{array}{c}0.019^{* * *} \\
(0.005)\end{array}$ & $\begin{array}{c}0.012^{* * *} \\
(0.003)\end{array}$ & $\begin{array}{c}0.005^{* * *} * \\
(0.002)\end{array}$ & $\begin{array}{l}-0.003 \\
(0.002)\end{array}$ & $\begin{array}{c}-0.012^{* * * *} \\
(0.004)\end{array}$ \\
\hline $\mathrm{Age}_{t-1}$ & $\begin{array}{c}-0.026 * * * \\
(0.008)\end{array}$ & $\begin{array}{l}-0.020 \\
(0.022)\end{array}$ & $\begin{array}{c}0.017 \\
(0.016)\end{array}$ & $\begin{array}{c}0.010 \\
(0.008)\end{array}$ & $\begin{array}{c}-0.010 * * \\
(0.005)\end{array}$ & $\begin{array}{c}-0.039^{* * *} \\
(0.006)\end{array}$ & $\begin{array}{c}-0.068^{* * *} \\
(0.012)\end{array}$ \\
\hline Foreign $_{t-1}$ & $\begin{array}{l}-0.001 \\
(0.018)\end{array}$ & $\begin{array}{c}0.008 \\
(0.038)\end{array}$ & $\begin{array}{c}0.001 \\
(0.034)\end{array}$ & $\begin{array}{l}-0.010 \\
(0.020)\end{array}$ & $\begin{array}{c}0.006 \\
(0.013)\end{array}$ & $\begin{array}{c}0.031^{* *} \\
(0.015)\end{array}$ & $\begin{array}{c}0.057^{* *} \\
(0.027)\end{array}$ \\
\hline Expint $_{t-1}$ & $\begin{array}{l}-0.000 \\
(0.000)\end{array}$ & $\begin{array}{l}-0.000 \\
(0.001)\end{array}$ & $\begin{array}{c}-0.001 * * * \\
(0.001)\end{array}$ & $\begin{array}{c}-0.001^{* *} \\
(0.000)\end{array}$ & $\begin{array}{c}-0.000^{* *} \\
(0.000)\end{array}$ & $\begin{array}{l}-0.000 \\
(0.000)\end{array}$ & $\begin{array}{c}0.001 \\
(0.001)\end{array}$ \\
\hline $\operatorname{Group}_{t-1}$ & $\begin{array}{c}0.009 \\
(0.012)\end{array}$ & $\begin{array}{l}-0.047 \\
(0.031)\end{array}$ & $\begin{array}{l}-0.032 \\
(0.024)\end{array}$ & $\begin{array}{l}-0.022^{*} \\
(0.012)\end{array}$ & $\begin{array}{l}-0.009 \\
(0.008)\end{array}$ & $\begin{array}{c}0.010 \\
(0.010)\end{array}$ & $\begin{array}{c}0.025 \\
(0.017)\end{array}$ \\
\hline $\mathrm{HC}_{t-1}$ & $\begin{array}{l}-0.000 \\
(0.000)\end{array}$ & $\begin{array}{l}-0.001 \\
(0.000)\end{array}$ & $\begin{array}{l}-0.000 \\
(0.000)\end{array}$ & $\begin{array}{c}0.000 \\
(0.000)\end{array}$ & $\begin{array}{c}0.000 \\
(0.000)\end{array}$ & $\begin{array}{c}0.000 \\
(0.000)\end{array}$ & $\begin{array}{l}-0.000 \\
(0.000)\end{array}$ \\
\hline Public $_{t-1}$ & $\begin{array}{c}0.016 \\
(0.011)\end{array}$ & $\begin{array}{c}0.014 \\
(0.020)\end{array}$ & $\begin{array}{l}0.035^{*} \\
(0.019)\end{array}$ & $\begin{array}{c}0.016 \\
(0.011)\end{array}$ & $\begin{array}{l}-0.003 \\
(0.007)\end{array}$ & $\begin{array}{c}0.002 \\
(0.010)\end{array}$ & $\begin{array}{c}-0.004 \\
(0.018)\end{array}$ \\
\hline Herfin $_{t-1}$ & $\begin{array}{l}-0.030 \\
(0.276)\end{array}$ & $\begin{array}{l}-0.132 \\
(0.292)\end{array}$ & $\begin{array}{l}-0.102 \\
(0.591)\end{array}$ & $\begin{array}{l}-0.108 \\
(0.337)\end{array}$ & $\begin{array}{c}0.038 \\
(0.180)\end{array}$ & $\begin{array}{c}0.010 \\
(0.224)\end{array}$ & $\begin{array}{l}-0.724 \\
(0.485)\end{array}$ \\
\hline Constant & $\begin{array}{c}0.057 \\
(0.050)\end{array}$ & $\begin{array}{c}0.359^{* * *} \\
(0.112)\end{array}$ & $\begin{array}{c}-0.438^{* * *} \\
(0.099)\end{array}$ & $\begin{array}{c}-0.233^{* * *} \\
(0.049)\end{array}$ & $\begin{array}{l}-0.014 \\
(0.033)\end{array}$ & $\begin{array}{c}0.205^{* * *} * \\
(0.045)\end{array}$ & $\begin{array}{c}0.638^{* * * *} \\
(0.088)\end{array}$ \\
\hline Observations & 3,336 & 3,336 & 3,336 & 3,336 & 3,336 & 3,336 & 3,336 \\
\hline$R^{2}$ & 0.010 & 0.042 & 0.046 & 0.023 & 0.006 & 0.022 & 0.052 \\
\hline
\end{tabular}


Table 12: Average Matching Estimates

\begin{tabular}{|c|c|c|c|c|}
\hline \multicolumn{5}{|c|}{ Average Treatment Effects on the Treated - PSM } \\
\hline Product Innovators & -0.00321 & 0.0143 & -0.22 & 0.823 \\
\hline Process Innovators & $0.02432^{*}$ & 0.0132 & 1.83 & 0.067 \\
\hline \multicolumn{5}{|c|}{ Average Treatment Effects on the Treated - NNM } \\
\hline & Coefficient & AI SE & $\mathrm{z}$ & $P>|z|$ \\
\hline Product Innovators & $-0.02614^{*}$ & 0.0143 & -1.83 & 0.068 \\
\hline Process Innovators & $0.03710^{* *}$ & 0.0153 & 2.41 & 0.016 \\
\hline \multicolumn{5}{|c|}{ Average Treatment Effects - PSM } \\
\hline & Coefficient & AI SE & $\mathrm{z}$ & $P>|z|$ \\
\hline Product Innovators & -0.00815 & 0.0142 & -0.57 & 0.566 \\
\hline Process Innovators & $0.03091^{*}$ & 0.0181 & 1.70 & 0.089 \\
\hline \multicolumn{5}{|c|}{ Average Treatment } \\
\hline & Coefficient & AI SE & $\mathrm{z}$ & $P>|z|$ \\
\hline Product Innovators & -0.02068 & 0.0139 & -1.48 & 0.138 \\
\hline Process Innovators & $0.05193^{* * *}$ & 0.0154 & 3.37 & 0.001 \\
\hline
\end{tabular}

Notes: $* * *, * *$ and $*$ indicate significance on a $1 \%, 5 \%$ and $10 \%$ level, respectively.

Table 13: Unconditional Quantile Treatment Effect Estimates

\begin{tabular}{cccccc}
\hline & $\mathrm{q} 10$ & $\mathrm{q} 25$ & $\mathrm{q} 50$ & $\mathrm{q} 75$ & $\mathrm{q} 90$ \\
\hline Product Innovators & -0.0082 & 0.0073 & -0.0043 & -0.0138 & $-0.0381^{*}$ \\
& $(0.0300)$ & $(0.0136)$ & $(0.0085)$ & $(0.0115)$ & $(0.0191)$ \\
Process Innovators & 0.0144 & 0.0210 & 0.0184 & $0.0502^{* *}$ & $0.0459^{*}$ \\
& $(0.0257)$ & $(0.0189)$ & $(0.0121)$ & $(0.0172)$ & $(0.0257)$
\end{tabular}

Notes: Standard errors in parenthesis. ${ }^{* * *},{ }^{*}$ and ${ }^{*}$ indicate significance on a $1 \%, 5 \%$ and $10 \%$ level, respectively. 